\title{
Hormonal Control of Weight Gain in Infants Recovering from Protein Energy Malnutrition. I. The Effect of Insulin and Metabolic Rate
}

\author{
HAZEL M. PAYNE ROBINSON, TERESA COCKS, DOUGLAS KERR, AND DAVID PICOU
}

The Tropical Metabolism Research Unit, University of the West Indies, Kingston 7, Jamaica

\section{Speculation}

During recovery from protein energy malnutrition, the augmented insulin release and metabolic rate that occurs with increased energy intake induces rapid rates of weight gain.

During recovery from protein energy malnutrition the rate of weight gain and the energy intake are closely related (1, 2, 25, 30, $36)$. The rate of weight gain is also positively correlated with metabolic rate $(3,7,30)$. However, the relationship of both rate of weight gain and metabolic rate to the output of plasma insulin has not been reported.

In malnutrition insulin output is low after intravenous glucose $(4,5,20,27)$, glucagon (27), and arginine (14) and there is a poor insulin release after a protein-glucose meal in untreated marasmic and marasmic-kwashiorkor infants (15). These responses improve after partial rehabilitation $(4,5,15,20,27)$. Whether or not abnormally low insulin release characteristic of protein energy malnutrition (PEM) persists after clinical recovery remains in doubt $(5,12,20,24,27)$. Most studies so far have compared insulin status in malnourished and clinically recovered children, and little attention has been paid to the intermediate phases of recovery where rate of weight gain may be 10 or 15 times the normal. This phase of extremely rapid weight gain has been termed "catch up growth."

In this study, therefore, the authors compared plasma insulin, metabolic rate, and other metabolic variables during the phase of rapid weight gain with those shown during malnutrition and after clinical recovery, using a physiologic stimulus - a high energy test meal.

\section{METHOD}

\section{SUBJECTS AND DIETARY TREATMENT}

Fifteen children with severe protein energy malnutrition were studied in a metabolic ward. Clinical data about these children are summarized in Table 1. The children were classified as marasmus, kwashiorkor, and marasmic-kwashiorkor according to the Wellcome criteria (38). During the first 3-4 days after admission to the ward, the children received a diet calculated to provide just sufficient energy and protein to maintain body weight without permitting growth (maintenance diet, Table 2). The formula contained glucose, dried skimmed milk, and peanut oil of which $64 \%$ of weight was carbohydrate, $3 \%$ protein, and $33 \%$ fat. The children were offered $468 \mathrm{~J}$ and $0.9 \mathrm{~g}$ protein $/ \mathrm{kg}$ body weight/day. Supplementary potassium chloride $(8 \mathrm{mEq} / \mathrm{kg} /$ day $)$, magnesium sulfate (4 mEq/ kg/day), ferrous sulfate (150 mg/day), and folic acid (5 $\mathrm{mg} /$ day) were given orally during this period. Subsequently, the chidren were placed on a high energy diet which is known to promote weight gain (Table 2). The formula contained whole milk, dextromaltose, sucrose, and peanut oil of which $32 \%$ was carbohydrate, $9 \%$ protein, and $59 \%$ fat. Children were offered $1046 \mathrm{~J}$ and $5.7 \mathrm{~g}$ protein/ $\mathrm{kg}$ body weight/day.
EXPERIMENTAL PROCEDURE

Informed parental consent was obtained for all studies. Professional peer review and approval of the proposed investigation was obtained. An initial study was done on eight of the children when malnourished (M) and on maintenance diet. No initial study was done on the others because they were either febrile or had vomiting, diarrhea, or specific infection. Thirty-one studies were done in 15 children during the period of rapid weight gain (R) and seven studies were done in seven clinically recovered children (C). Those children who passed the expected weight for their height and continued to gain weight rapidly were included in the recovering group (R). All studies were conducted in the early afternoon after a 4-hr fast. One hr before the study, a slow iv infusion of saline was set up in order to obtain serial blood samples without disturbing the child and oral paraldehyde $(0.5 \mathrm{ml} / \mathrm{kg}$ body weight $)$ was administered via a nasogastric tube. A 4-hr fasting metabolic rate was estimated from oxygen consumption and carbondioxide production using a Kipp and Zonen Noyons diaferometer. The instrument was calibrated by combusting known amounts of alcohol in the hood for the child. Observations of respiratory exchange made for 5 successive min were averaged and the results for each interval combined. A blood sample was withdrawn immediately before the test meal (Table 2 ) was given by nasogastric tube. The meal provided 174 joules and $0.9 \mathrm{~g}$ protein $/ \mathrm{kg}$ body weight. Postprandial metabolic rate was measured at $10 \mathrm{~min}$ and, thereafter, at 15 -min intervals for $90 \mathrm{~min}$. Blood samples were taken at 15, 30, 60, 90, and 120 min. Blood was collected in tubes containing EDTA $(1 \mathrm{mg} \mathrm{ml})$ and immediately centrifuged at 600 $\mathrm{g}$ for $8 \mathrm{~min}$ at $4^{\circ} \mathrm{C}$. Plasma was immediately removed and stored at $-20^{\circ} \mathrm{C}$ until analysis.

\section{ANALYTICAL METHODS}

All plasma determinations were performed in duplicate. Glucose was determined by the glucose oxidase method of Huggett and Nixon (19), $\alpha$-amino nitrogen by the method of Moore and Stein (28) and triglyceride by the method of Carlson (8). Insulin was assayed by the double antibody method of Hales and Randle (16) using reagents supplied in a kit from the Radiochemical Centre, Amersham. The insulin immunoassay method was modified for increased sensitivity in the range $1-20 \mu \mathrm{U} / \mathrm{ml}$ as previously described $(26,32)$. The authors increased the dilution of the double antibody reagent 5 times, extended the first incubation period in the absence of labeled insulin from 6 to $18 \mathrm{hr}$, and shortened the second period of incubation with labeled insulin from 18 to $6 \mathrm{hr}$. There was a $50 \%$ displacement of bound ${ }^{125} \mathrm{I}$ insulin by approximately $0.5 \mu \mathrm{U}$ of insulin $(0.1 \mathrm{ml}$ of $5 \mu \mathrm{U} / \mathrm{ml})$. The reproducibility of 50 replicate determinations of plasma samples containing between $1-10 \mu \mathrm{U} / \mathrm{ml}$ was $\pm 1.0 \mu \mathrm{U} / \mathrm{ml}$ (SD). In comparison with the standard double antibody method, the variance in this range was reduced to one-third, and fasting plasma samples were found on the average to contain about $3 \mu \mathrm{U} / \mathrm{ml}$ less insulin. Dilution of samples produced linear results and there was complete recovery of insulin added to plasma. EDTA plasma was 
Table 1. Clinical data

\begin{tabular}{|c|c|c|c|c|c|c|}
\hline Subject & Age (months) & Height $(\mathrm{cm})$ & $\begin{array}{c}\text { Minimum weight } \\
\text { after admission }(\mathrm{kg})\end{array}$ & $\begin{array}{l}\text { Weight for age }{ }^{1} \\
(\%)\end{array}$ & $\begin{array}{l}\text { Weight for } \\
\text { height }^{2}(\%)\end{array}$ & Diagnosis \\
\hline 1 & 22 & 69 & 5.7 & 47 & 70 & Marasmic-kwashiorkor \\
\hline 2 & 15 & 70 & 5.6 & 53 & 69 & Marasmus \\
\hline 3 & 7 & 61 & 4.3 & 53 & 73 & Marasmus \\
\hline 4 & 12 & 68 & 5.9 & 59 & 78 & Marasmic-kwashiorkor \\
\hline 5 & 9 & 65.5 & 5.1 & 59 & 71 & Marasmus \\
\hline 6 & 24 & 67.5 & 5.6 & 45 & 71 & Marasmus \\
\hline 7 & 9 & 61 & 3.6 & 41 & 66 & Marasmus \\
\hline 8 & 16 & 69.5 & 4.9 & 46 & 61 & Marasmic-kwashiorkor \\
\hline 9 & 19 & 70 & 6.2 & 54 & 74 & Marasmic-kwashiorkor \\
\hline 10 & 17 & 72 & 6.7 & 61 & 76 & Marasmus \\
\hline 11 & 6 & 58.5 & 3.9 & 53 & 74 & Marasmus \\
\hline 12 & 14 & 73.5 & 7.7 & 75 & 81 & Kwashiorkor \\
\hline 13 & 19 & 79.5 & 8.7 & 75 & 80 & Kwashiorkor \\
\hline 14 & 15 & 71.5 & 7.9 & 75 & 84 & Kwashiorkor \\
\hline 15 & 13 & 63.3 & 4.9 & 47 & 73 & Marasmic-kwashiorkor \\
\hline Mean & 15 & 67.9 & 5.8 & 56.1 & 73.2 & \\
\hline SD & 5 & 5.5 & 1.5 & 11.3 & 5.9 & \\
\hline
\end{tabular}

${ }^{1}$ Weight expressed as a \% of a normal child of the same age using the 50th Percentile of the Harvard standard (34).

${ }^{2}$ Weight expressed as a \% of a normal child of the same height using the 50th Percentile of the Harvard standard.

Table 2. Composition by weight and energy of (1) Maintenance and Recovery Diets (2) the test meal

\begin{tabular}{|c|c|c|c|c|c|c|c|}
\hline & \multicolumn{2}{|c|}{ Carbohydrate } & \multicolumn{2}{|c|}{ Protein } & \multicolumn{2}{|c|}{ Fat } & \multirow{2}{*}{$\begin{array}{c}\text { Energy } \\
\mathrm{J} / \mathrm{kg} / \text { day }\end{array}$} \\
\hline & $\%$ & $\mathrm{~g} / \mathrm{kg} /$ day & $\%$ & $\mathrm{~g} / \mathrm{kg} /$ day & $\%$ & $\mathrm{~g} / \mathrm{kg} /$ day & \\
\hline $\begin{array}{l}\text { Maintenance diet (glucose, dried skim milk, } \\
\text { arachis oil) }\end{array}$ & 64 & 19.2 & 3 & 0.9 & 33 & 9.9 & 468 \\
\hline $\begin{array}{l}\text { Recovery diet (dextromaltose, sucrose, whole } \\
\text { milk, arachis oil) }\end{array}$ & 32 & 20.3 & 9 & 5.7 & 59 & 36.1 & 1046 \\
\hline \multirow[t]{2}{*}{ Test Meal ${ }^{1}$} & \multicolumn{2}{|r|}{$\mathrm{g} / \mathrm{kg}$} & \multicolumn{2}{|c|}{$\mathrm{g} / \mathrm{kg}$} & \multicolumn{2}{|r|}{$\mathrm{g} / \mathrm{kg}$} & $\mathrm{J} / \mathrm{kg}$ \\
\hline & \multicolumn{2}{|r|}{3.4} & \multicolumn{2}{|c|}{0.9} & \multicolumn{2}{|r|}{6.0} & 174 \\
\hline
\end{tabular}

${ }^{1}$ The composition of the test meal and the recovery diet was the same.

found to give the same value as serum, whereas heparinized plasma gave slightly higher values. This agrees with the original observations of Henderson (18).

Rate of weight change was calculated at the time of each study as an average of the daily weight change expressed per $\mathrm{kg}$ body weight for 4-7 days. During the malnourished and clinically recovered phases, the rate of weight change was taken over a period of 4 days before the test, and during the phase of rapid weight gain, the rate of weight change was taken 3 days before and 3 days after the test. The total postprandial response for each variable measured was calculated from the area under the curve for $120 \mathrm{~min}$ and expressed in arbitrary units. The significance of the difference between means was analysed by students $t$ test. Regression lines and correlation coefficients were calculated by the method of least squares.

\section{RESULTS}

Comparison of studies in malnourished, recovering, and clinically recovered phases.

\section{RATES OF WEIGHT GAIN}

Figure 1 shows some typical patterns of weight gain during recovery. In order to make comparisons between the different phases of recovery, the malnourished phase (M) was defined as the period from admission to the onset of high energy feeding that usually coincided with the beginning of weight gain; the phase of rapid weight gain ( $R$ ) (catch up) was taken as the period from the onset of high energy feeding until expected weight for height had been reached; the phase of clinical recovery (C) lasted from the end of phase $\mathrm{R}$ until discharge from hospital. As shown in Table 3 , the average rate of weight change in $M$ children was $-6.5 / \mathrm{kg}$ body weight/day; their energy and protein intakes were $389 \mathrm{~J}$ and $0.75 \mathrm{~g}$ protein $/ \mathrm{kg}$ body weight/day. In the second group of studies, $(\mathrm{R})$, the children were gaining weight at a mean rate of $10 \mathrm{~g} / \mathrm{kg}$ body weight/day. Their mean daily energy and protein intake was $703 \mathrm{~J}$ and $3.9 \mathrm{~g}$ protein $/ \mathrm{kg}$ body weight/day. In the third group (C), the children had reached their expected weight for height and had voluntarily reduced their energy and protein intake to $452 \mathrm{~J}$ and $2.5 \mathrm{~g}$ protein $/ \mathrm{kg}$ body weight/day. In this group, the mean rate of weight change $-0.1 \mathrm{~g} / \mathrm{kg}$ body weight/day. The mean rates of weight change were significantly different in the three groups. The rate of weight change was significantly correlated with energy intake $(r=0.88, P<0.001)$.

\section{FASTING VALUES}

Table 4 gives the 4-hr fasting values of metabolic rate, plasma insulin, glucose, $\alpha$-amino nitrogen, triglyceride, and metabolic rate in children in the three clinical states. The main points shown by this table are: (1) the fasting insulin level was low in the malnourished children; (2) the fasting glucose and triglyceride concentrations were lower in the malnourished children; (3) the metabolic rate was significantly lower in the malnourished children than during or after recovery. In the three groups taken together, the fasting metabolic rate was significantly correlated with the rate of weight change (Fig. 2).

\section{RESPONSES TO A TEST MEAL}

The postprandial responses of plasma insulin, glucose, $\alpha$-amino nitrogen, triglyceride, and metabolic rate are shown in Figure 3 and are summarized in Table 5 . In this table, the results are expressed as arbitrary units of the area under the curve, after subtraction of the zero time value. (1) The postprandial insulin 
response in the malnourished group was significantly lower than that of children during the phase of rapid weight gain $(P<0.05)$ and after clinical recovery $(P=0.002)$. In all three groups, the highest mean insulin concentration occurred at $30 \mathrm{~min}$ after the test meal. (2) The glucose response was significantly greater during the phase of rapid weight gain $(P=0.02)$ and after clinical recovery $(P=0.002)$ than during malnutrition. The plasma glucose concentration returned to basal values at $120 \mathrm{~min}$ in the children both when they were malnourished and also during rapid weight gain, but when they were clinically recovered, the value at 120 min was significantly elevated above basal values $(P<0.02)$. (3) As shown in Figure 4, the insulin/glucose ratios were significantly higher in recovering or clinically recovered than in malnourished children. (4) There was no significant difference between the M, $\mathrm{R}$, and recovered children in the responses of plasma $\alpha$-amino nitrogen, and triglyceride to the test meal. In the $\mathbf{M}$ children, the triglyceride level showed only a small and gradual increase over

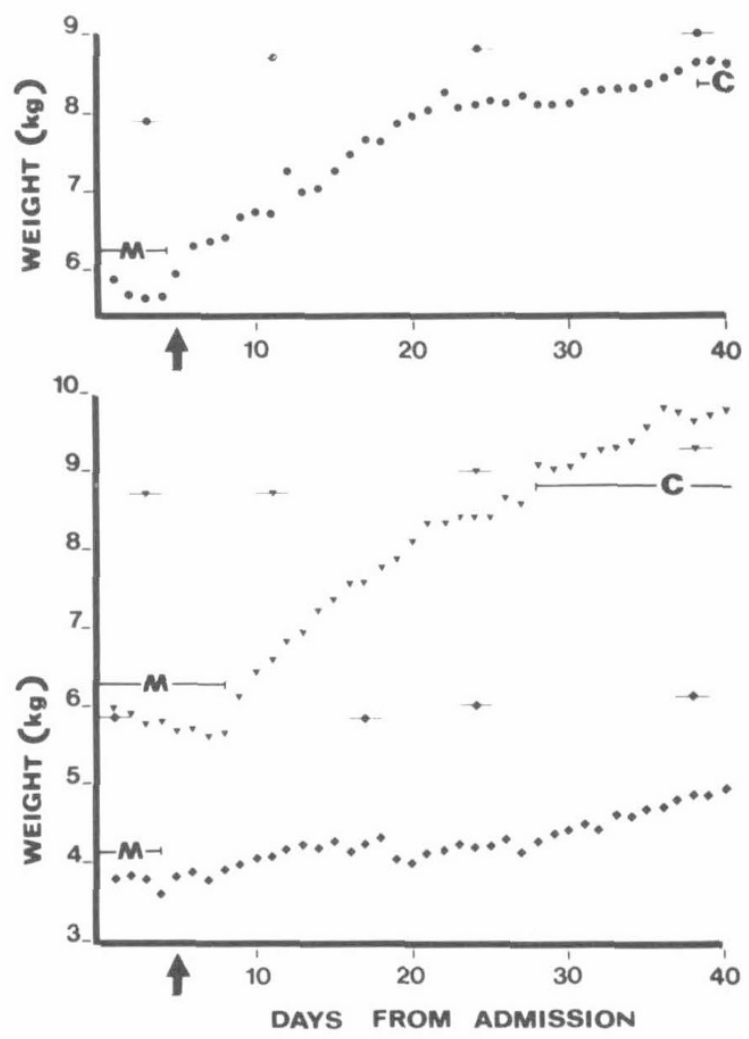

Fig. 1. Typical weight curves seen during recovery from malnutrition. The "catch up growth" phase is shown in the interval between $\mathbf{M}$ and $\mathrm{C}$. The symbol - indicates the expected weight for height. The arrow at 5 days after admission indicates the onset of high energy feeding. In the upper figure, an example of a normal recovery weight chart is shown. The middle figure is an example in which weight loss persists for a few days after the onset of high energy feeding, then weight gain is very rapid, and continues rapidly after expected weight for height is reached. In the lower figure, rate of weight gain is slow throughout the period of recovery. the $2 \mathrm{hr}$ after the meal, whereas in the other two groups there was a well-defined peak at $1 \mathrm{hr}$. (5) The postprandial increase in metabolic rate was much less in the $M$ than in the $R$ or recovering children. The peak insulin response invariably preceded the peak metabolic rate response.

The interrelationships between the responses to the test meal are interesting, even though statistical correlations are not evidence of cause and effect. Table 6 shows the correlations betwen the responses in all three groups taken together. The results show that (1) rate of weight change was positively correlated with energy intake, postprandial metabolic rate, and insulin, (Fig. 5) and that (2) postprandial metabolic rate and plasma insulin were interrelated. (Fig. 6).

\section{DISCUSSION}

During recovery from protein energy malnutrition these patients undergo markedly different phases, which represent in many ways extremes of metabolic activity. The $M$ child has been on a starvation diet for a long time, and has reduction in both metabolic mass and activity. Thus, there is a low metabolic rate, fasting insulin level, and reduced insulin response. There may be intestinal atrophy with malabsorption syndrome, $(21,22)$ impaired hepatic function (6), and pancreatic dysfunction (13). Although Weinkove et al. (37) have observed no marked differences in ultrastructure of control and malnourished rat endocrine pancreas, a $40 \%$ reduction in total pancreatic islet volume was shown in malnourished rats. Other abnormalities in islet morphology have been demonstrated by light microscopy. There is pancreatic atrophy $(6,13,29)$, loss of insulin granules, reduction in $\beta$ cell size with inactive hyperchromatic nuclei and increased ratio of $\alpha$ to $\beta$ cells $(17,31)$.

In these circumstances, it can be appreciated readily that disturbances of the entero-insular axis may bright about abnormal peripheral blood responses of glucose and insulin to a stimulus. There must be normal intestinal absorption, gut hormone release, $\beta$ cell mass and responsiveness, as well as normal hepatic function. None of these are known to be normal in malnutrition.

Fasting for even a short time may lead to glucose intolerance and previous administration of glucose before tests of $\beta$ cell function increases the secretion of insulin $(9,10)$. The antecedent diet is, thus, also an important determinant of the response obtained to a test meal. We deliberately chose to use the physiologic stimulus of a standard high energy test meal of carbohydrate, fat, and milk protein because rapid recovery is usually achieved when an identical diet is given to severely malnourished children. The authors, therefore, believe that the hormonal responses they have shown are the same responses that obtain from day to day in these children.

In this study as in others, there was an inadequate antecedent diet to the test in the malnourished state. It is not possible to assess how much this lack of priming is influencing the results, because when an adequate antecedent diet is given the child starts to recover. The rapid recovery of the insulin response on commencing a rehabilitation diet suggests that this is a major factor and certainly the changes leading to the impaired entero-insular axis in malnutrition are usually capable of rapid reversal.

Table 3. Rate of weight change and energy intake, in $M, R$, and $C$ children. See text for method of calculating rate of weight change. Mean $\pm S E M$

\begin{tabular}{|c|c|c|c|c|}
\hline & M & $\mathrm{R}$ & $\mathrm{C}$ & $P$ values \\
\hline No. of subjects & 8 & 15 & 7 & \\
\hline No. of studies & 8 & 31 & 7 & \\
\hline Rate of weight change ( $\mathrm{g} / \mathrm{kg} /$ day) & $-6.5 \pm 1.09$ & $10.0 \pm 0.9$ & $-0.1 \pm 0.7$ & $\begin{array}{l}\mathrm{M} \text { vs. } \mathrm{R}<0.001 \\
\mathrm{R} \text { vs. } \mathrm{C}<0.001 \\
\mathrm{M} \text { vs. } \mathrm{C}=0.01\end{array}$ \\
\hline Mean energy intake $(\mathrm{J} / \mathrm{kg} /$ day $)$ & $389 \pm 13$ & $703 \pm 25$ & $452 \pm 38$ & $\begin{array}{l}\text { M vs. } \mathrm{R}<0.001 \\
\mathrm{R} \text { vs. } \mathrm{C}<0.001 \\
\mathrm{M} \text { vs. } \mathrm{C} \text { NS }\end{array}$ \\
\hline
\end{tabular}


Table 4. Fasting values of plasma insulin, glucose, $\alpha$-amino nitrogen, triglyceride, and metabolic rate. Mean $\pm S E M$ in $M, R$, and $C$ children

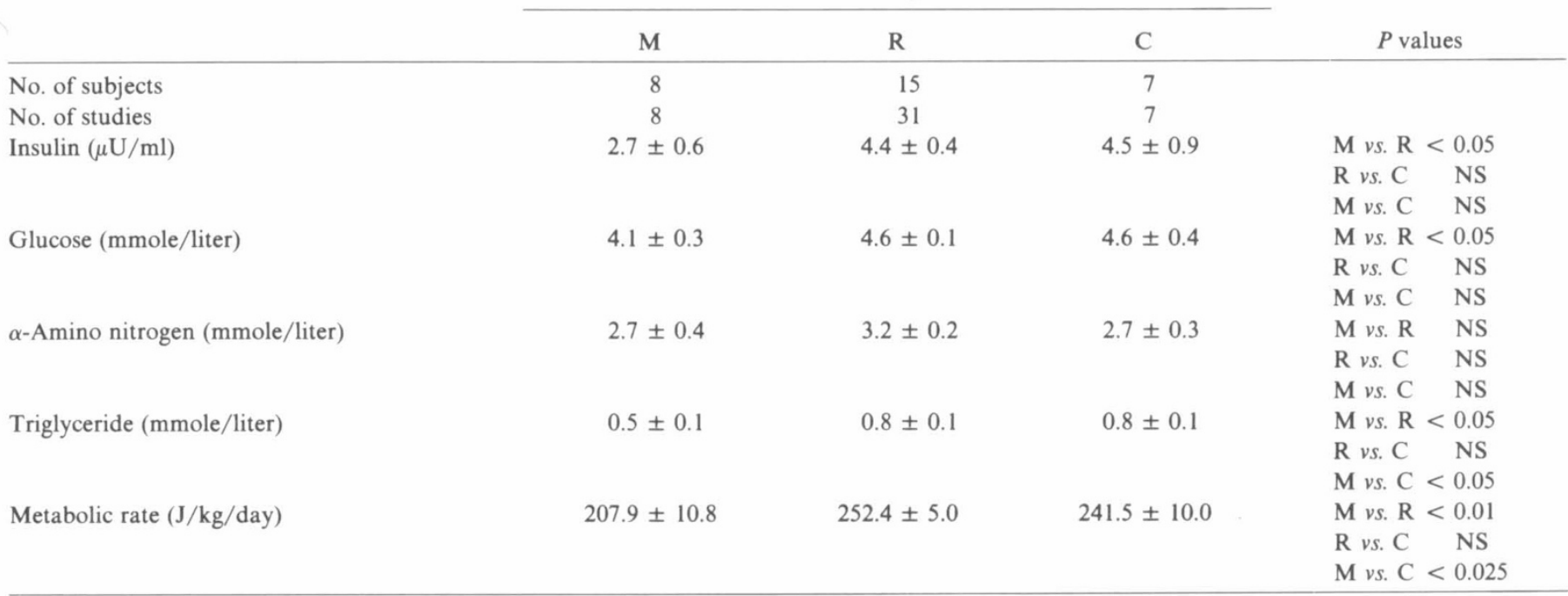

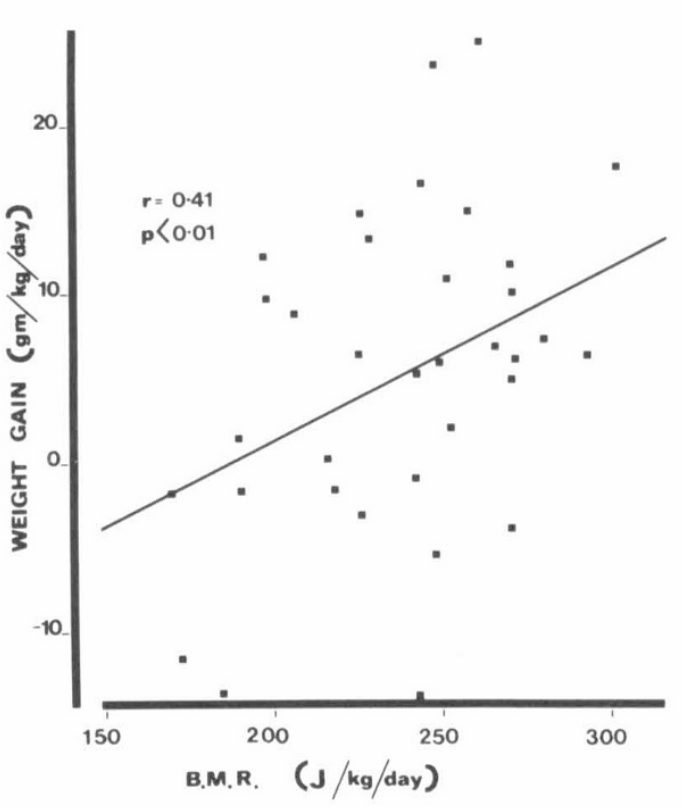

Fig. 2. The relationship between fasting metabolic rate and rate of weight change in $\mathrm{M}, \mathrm{R}$, and $\mathrm{C}$ children. The mean daily rate of weight change was calculated over a period of 4 days before the test in the malnourished and recovered children, and over a period of 7 days in the recovering children (See text). The regression line fits the equation derived from the method of least squares, $\mathrm{y}=0.5 \mathrm{x}-23.65(r=0.41, P<0.01)$.

In contrast to the $\mathrm{M}$ child, the $\mathrm{R}$ child could be described as hypermetabolic. The increase in rate of weight gain of up to 20 times normal is dramatic. This is associated with substantial increases in postprandial metabolic rate and led to the hypothesis that during recovery, the postprandial metabolic rate increase reflects the energy expended in new tissue deposition. Insulin as an anabolic hormone is intimately involved in the control of new tissue synthesis, both protein tissue and adipose tissue. Indeed, it has been postulated that the children who fail to gain weight rapidly have an insufficiency of insulin because they repeatedly found low fasting and poststimulation plasma insulin level in these particular children (33).

The authors have confirmed the correlation of both energy intake and postprandial metabolic rate with the rate of weight gain. Both rate of weight gain and postprandial metabolic rate are positively correlated with the postprandial insulin response. In-

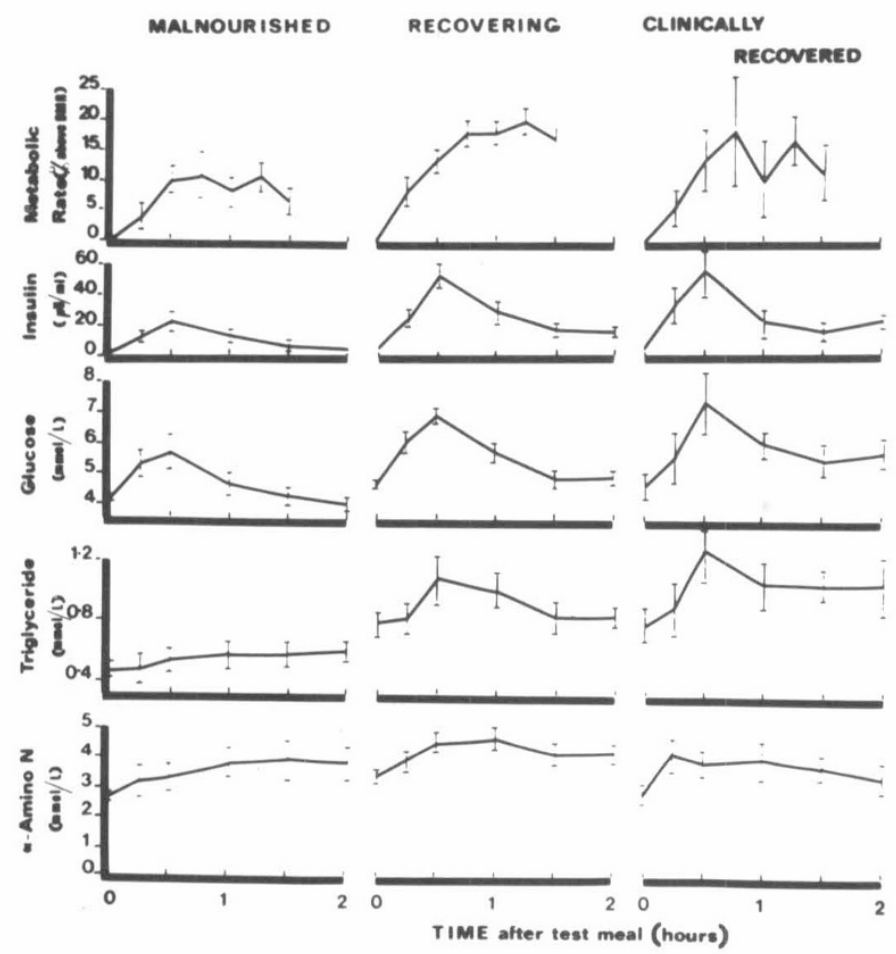

Fig. 3. Postprandial responses in metabolic rate, plasma insulin, plasma glucose, plasma triglyceride, plasma $\alpha$-amino nitrogen in $\mathrm{M}, \mathrm{R}$, and $\mathrm{C}$ children. Values are expressed as means \pm SEM.

sulin stimulates protein synthesis, and antagonizes the hormones involved in amino acid catabolism. Thus, it promotes the deposition of new tissue. The increased rate of weight gain and metabolic activity associated with the increased insulin output (area under the postprandial plasma insulin curve) suggests that insulin is a dominant mediator in vivo in promoting new tissue synthesis and hence growth. This is supported by the consistent finding that the maximum insulin levels preceded the peak rise in metabolic rate even in those studies where the peak insulin response was delayed. The authors, therefore, would agree with the hypothesis (11) that a relative deficiency of insulin during this phase may limit the rate at which these children recover. As a corollary of this, most $\mathbf{M}$ children are capable of a supranormal insulin output when they are fed increased dietary intakes. Their $\beta$ cells must dramat- 
Table 5. A comparison of postprandial responses ${ }^{1}$ for plasma insulin, glucose, $\alpha$-amino nitrogen, triglyceride, and metabolic rate (mean \pm $S E M)$ in $M, R$, and $C$ children

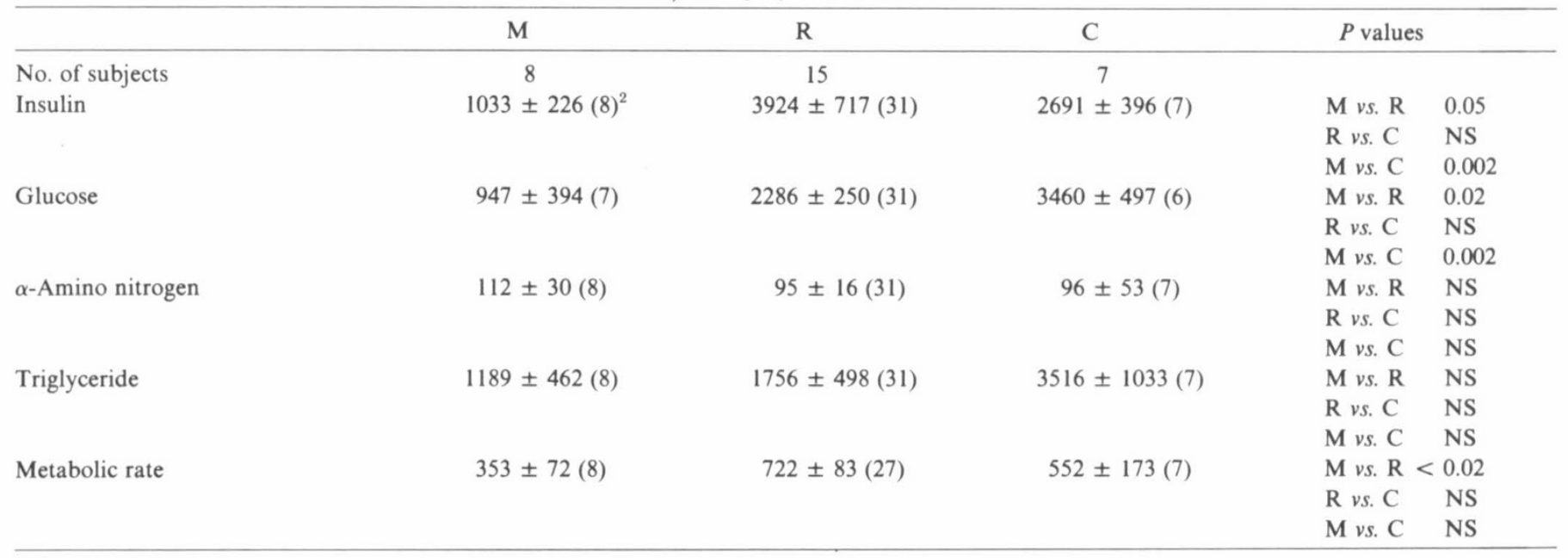

\footnotetext{
${ }^{1}$ Values are arbitrary units calculated from the area under the curve after subtraction of zero time (fasting) values.

${ }^{2}$ Number of studies in parentheses.
}

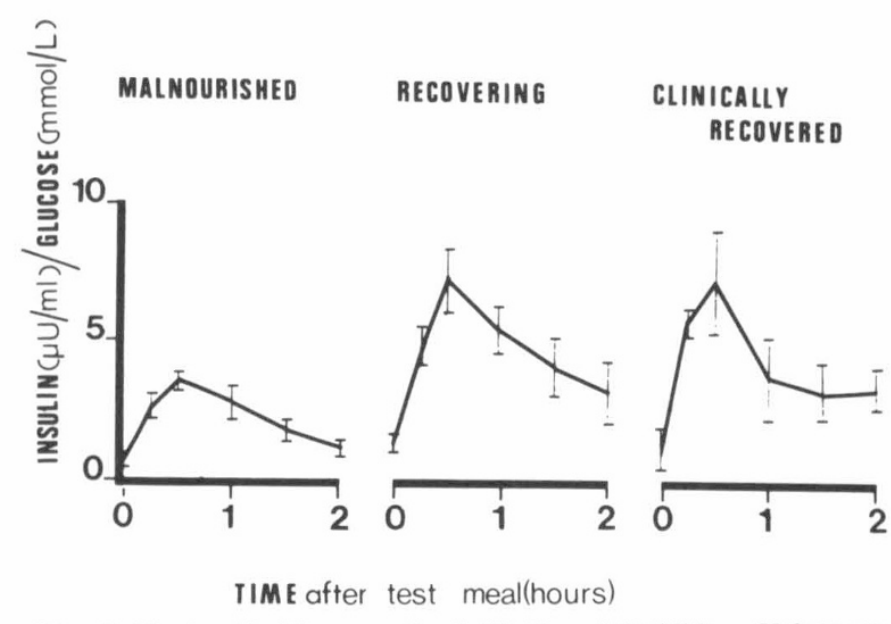

Fig. 4. The insulin/glucose ratios in $\mathrm{M}, \mathrm{R}$, and $\mathrm{C}$ children. Values are expressed as means \pm SEM.

Table 6. Interrelationships between rate of weight change, energy intake, and the responses ${ }^{1}$ to a test meal. Results from malnourished, recovering, and recovered children taken together

\begin{tabular}{lccc}
\hline & $n$ & $r$ & $P$ \\
\hline $\begin{array}{l}\text { Rate of weight change } v s . \\
\quad \text { energy intake }\end{array}$ & 46 & +0.88 & $<0.001$ \\
$\quad$ metabolic rate response & 43 & +0.37 & $<0.05$ \\
$\quad$ insulin response & 41 & +0.44 & $<0.01$ \\
& & & \\
Insulin response $v s$. & 43 & +0.53 & $<0.001$ \\
$\quad$ metabolic rate response & 39 & +0.40 & $<0.01$ \\
glucose response & 40 & +0.10 & $\mathrm{NS}$ \\
$\quad \begin{array}{l}\alpha \text {-amino nitrogen response } \\
\text { triglyceride response }\end{array}$ & 41 & +0.10 & $\mathrm{NS}$ \\
\hline
\end{tabular}

\footnotetext{
${ }^{1}$ The responses to the test meal were calculated as the area under the curve (Fig. 3) after subtraction of the zero-time (fasting) values.
}

ically increase their synthesis and secretion of insulin. A comment should be made on the use of sedation in these experiments. While it is acknowledged that sedatives may affect hormonal responses, it is doubtful that the marked differences shown between the groups were unduly influenced by the paraldehyde, because it was administered in all tests.

When the children have reached their expected weight for height, they start to refuse feeds and their rate of weight gain

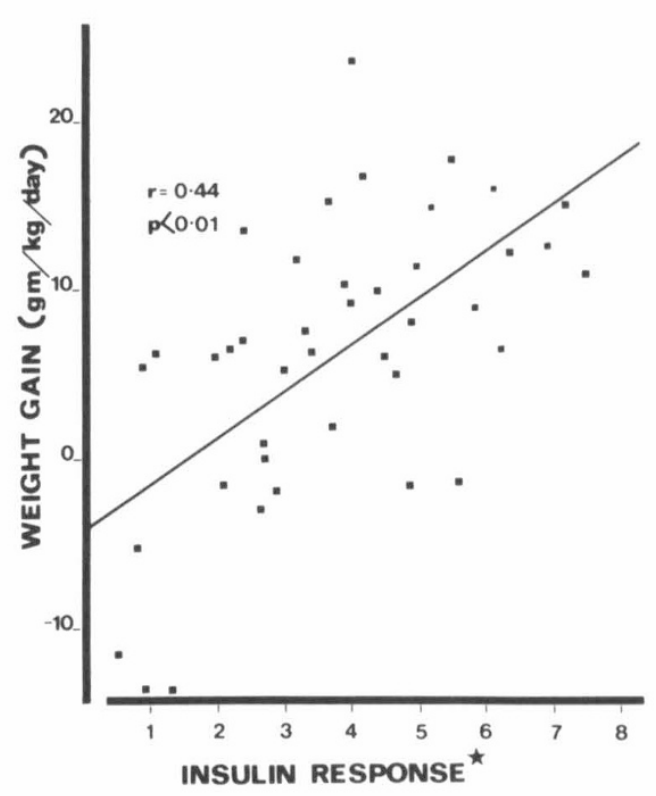

Fig. 5. The relationship between rate of weight change and postprandial insulin response in children $\mathrm{M}, \mathrm{R}$, and $\mathrm{C}$. The regression line fits the equation derived from the method of least squares, $\mathrm{y}=2.72 \mathrm{x}-4.06(r=$ $0.44, P<0.01$ ).

normally falls quite suddenly. It is slightly above the normal rate of weight gain as the children are experiencing an increased rate of gain of height. These children had smaller postprandial rises in insulin and metabolic rate than rapidly growing children but much larger increments than the $\mathbf{M}$ children. There is no evidence for an impairment of insulin synthesis and release on recovery in our children and the normal insulin:glucose ratios suggest that the peripheral action of insulin is also normal. Persistent impairment of insulin release was inferred from abnormal glucose tolerance tests (20) and also the impaired response to glucagon (27). In contrast to these latter studies, normal fasting insulin and insulin responses to oral glucose, iv glucagon, and tolbutamide in patients recovered from kwashiorkor have been reported (24), both shortly after recovery and 10-yr follow up (5). Of the few children (approximately 10\%) who do not recover fully, many have persistent impairment of carbohydrate homeostasis related to an insufficiency of insulin. Although supplemental insulin may improve carbohydrate homeostasis and accelerate recovery in those children who fail to gain weight satisfactorily in spite of an 


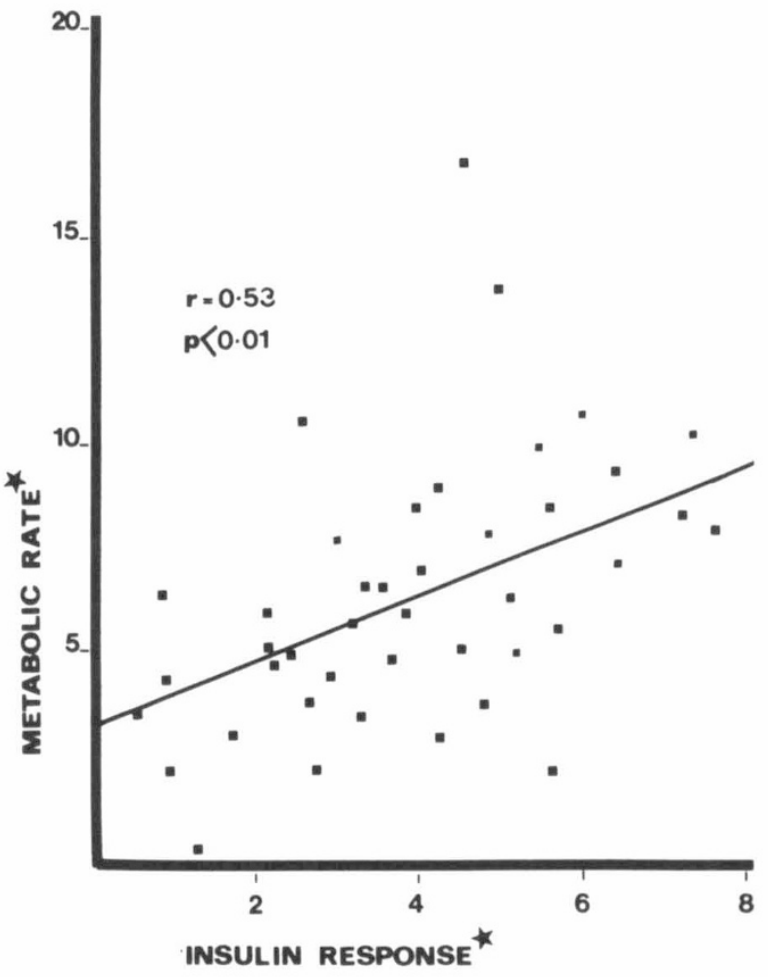

Fig. 6. The relationship between postprandial insulin response and postprandial metabolic rate in $\mathrm{M}, \mathrm{R}$, and $\mathrm{C}$ children. The regression line fits the equation derived from the method of least squares, $\mathrm{y}=0.82 \mathrm{x}+$ $3.10(r=0.53, P<0.01)$.

adequate diet (23), such treatment cannot be recommended because dangerous levels of hypoglycaemia may occur in malnutrition. These results suggest that the altered hormonal status in malnutrition may represent adaptive mechanisms that have survival value under conditions of prolonged dietary deprivation. The reduction in metabolic rate consequent on the reduction in insulin output permits metabolic homeostasis in the absence of a nutrient supply. The greatly augmented secretion of insulin and increased metabolic rate that occurs in most cases immediately after the onset of high energy feeding is related to increased metabolic activity leading to increased tissue deposition during recovery. This hypothesis is supported by the significant relationships between rate of weight change, calorie intake, insulin output, and metabolic rate.

\section{REFERENCES AND NOTES}

1. Ashworth, A., Bell, R., James, W. P. T., and Waterlow, J. C.: Calorie requirements of children recovering from protein-calorie malnutrition. Lancet, 2: 600 (1968).

2. Ashworth, A.: Growth rates in children recovering from protein-calorie malnutrition. Brit. J. Nutr., 23: 835 (1969).

3. Ashworth, A.: Metabolic rates during recovery from protein-calorie malnutrition: the need for a new concept of specific dynamic action. Nature, 223: 407 (1969).

4. Baig, H. A., and Edozien, J. C.: Carbohydrate metabolism in kwashiorkor. Lancet, 2: 662 (1965).

5. Becker, D. J., Pimstone, B. L., Hansen, J. D. L., and Hendricks, S.: Insulin secretion in protein-calorie malnutrition. I, Quantitative abnormalities and response to treatment. Diabetes, 20: 542 (1971).

6. Bras, G., Waterlow, J. C., and De Pass, E.: Further observations on the liver, pancreas and kidney in malnourished infants and children. J. Trop. Paediatr., 2: 147 (1956)

7. Brooke, O. G., and Ashworth, A.: The influence of malnutrition on the postprandial metabolic rate and respiratory quotient. Brit. J. Nutr., 27: 407 (1972).

8. Carlson, L. A.: Determination of serum triglycerides, J. Atheroscler. Res., 3: 334 (1963).

9. Cerasi, E., Fick, G., Rudemo, M.: A mathematical model for the glucose induced insulin release in man. Europ. J. Clin. Invest., 4: 267 (1974).

10. Cerasi, E.: Mechanisms of glucose stimulated insulin secretion in health and in diabetes: Some re-evaluations and proposals. (Review article). Diabetologia, 11: 1 (1975).

11. Cheek, D. B., Hill, D. E., Cordano, A., and Graham, G. G.: Malnutrition in infancy: changes in muscle and adipose tissue before and after rehabilition. Pediatr. Res., 4: 135 (1970).

12. Cook, G. C.: Glucose tolerance after kwashiorkor. Nature, 215: 1295 (1967)

13. Davies, J. N. P.: The essential pathology of kwashiorkor. Lancet, 1: 317 (1948).

14. Graham, G. G., Cordano, A., Blizzard, R. M., and Cheek, D. B.: Infantile malnutrition: changes in body composition during rehabilitation. Pediatr. Res., 3. 579 (1969)

15. Graham, G. G., Nakashima, J., Thompson, R. G., and Blizzard, R. M.: Metabolic and hormonal responses to a protein glucose meal in normal infants and in marasmus and marasmic kwashiorkor. Pediatr. Res., 10: 832 (1976).

16. Hales, C. N., and Randle, P. J.: Immunoassay of insulin with insulin-antibody precipitate. Biochem. J., 88: 137 (1963)

17. Heard, C. R. C. and Stewart, R. J. C.: Protein calorie deficiency and disorders of the endocrine glands. Hormones, 2: 40 (1971).

18. Henderson, J. R.: Serum insulin or plasma insulin? Lancet, 2: 545 (1970).

19. Huggett, A. S., and Nixon, D. A.: Use of glucose oxidase, peroxidase, and o-dianisidine in the determination of blood and urinary glucose. Lancet, 2:368 (1957).

20. James, W. P. T., and Coore, H. G.: Persistent impairment of insulin secretion and glucose tolerance after malnutrition. Am. J. Clin. Nutr., 23: 386 (1970).

21. James, W. P. T.: Sugar absorption and intestinal motility in children when malnourished and after treatment. Clin. Sci., 39: 305 (1970).

22. James, W. P. T.: Jejunal disaccharidase activities in children with marasmus and with kwashiorkor. Arch. Dis. Childhood, 46: 218 (1971).

23. Jelliffe, D. B.: Protein-Calorie Malnutrition. In: Child Health in the Tropics p. 57 (1968).

24. Kajubi, S. K.: The endocrine pancreas after kwashiorkor. Am. J. Clin. Nutr. 25: 1140 (1972).

25. Kerr, D., Ashworth, A., Picou, D., Poulter, N., Seakins, A., Spady, D., and Wheeler, E.: Accelerated recovery from infant malnutrition with high calorie feeding. In: L. I. Gardner and P. Amacher: Endocrine aspects of Malnutrition: p. 467 (The Kroc foundation, Santa Ynez, California, 1973).

26. Kerr, D. S., Stevens, M. C. G., and Robinson, H. M.: Fasting metabolism in infants I: Effect of severe undernutrition on energy and protein utilization. Metabolism, 27 (4): 411 (1978).

27. Milner, R. D. G.: Metabolic and hormonal responses to glucose and glucagon in patients with infantile malnutrition. Pediatr. Res., 5: 33 (1971).

28. Moore, S., and Stein, W. H.: A modified Ninhydrin reagent for the photometric determination of amino acids and related compounds. J. Biol. Chem., 211: 907 (1954).

29. Normet, L.: Bull. Soc. Path. exot. 19: 207 (1926) quoted by Trowell Davies and Dean: In kwashiorkor. Edward Arnold, London (1954)

30. Parra, A., Garza, C., Garza, Y., Saravia, J. L., Hazelwood, C. F., and Nichols, B. L.: Changes in growth hormone, insulin, and thyroxine values and in energy metabolism of marasmic infants. J. Pediatr. 82: 133 (1973).

31. Platt, B. S., and Stewart, R. J. C. Experimental protein calorie deficiency: histopathological changes in the endocrine glands of pigs. J. Endocrinol, 38 (2): 121 (1967).

32. Robinson, H., and Picou, D.: A comparison of fasting plasma insulin and growth hormone concentration in marasmic, kwashiorkor, marasmic-kwashiorkor, and underweight children. Pediatr. Res., 11: 637 (1977).

33. Robinson, H., Cocks, T., Kerr, D., and Picou, D.: Fasting and postprandial levels of plasma insulin and growth hormone in malnourished Jamaican children, during catch-up growth and after complete recovery. In: L. I. Gardner, P. Amacher: Endocrine Aspects of malnutrition. p. 45 Kroc Foundation, (Santa Ynez, CA, (1973)

34. Vaughan, V. C.: Developmental pediatrics. Growth and development. In: W. E. Nelson, V. C. Vaughan, and R. J. McKay: Textbook of Pediatrics p. 15 (W. B. Saunders, Co., Philadelphia, 1969).

35. Waterlow, J. C., Wills, V. G., and Gyorgy, P.: Balance studies in malnourished Jamaican infants. 2. Comparison of absorption and retention of nitrogen and phosphorus from human milk and a cow's milk mixture. Brit. J. Nutr., 14: 199 (1960).

36. Waterlow, J. C.: The rate of recovery of malnourished infants in relation to the protein and calorie levels of the diet. J. Trop. Pediatr., 7: 16 (1961).

37. Weinkove, C., Weinkove, E. A., and Pimstone, B. L.: Insulin release and pancreatic islet volume in malnourished rats. S. A. Med. J. (Supplement-S. A. Journ. of Lab. and Clin. Med.) 48: 1888 (1974).

38. Wellcome Classification: Classification of Infantile Malnutrition. Lancet, 2: 302 (1970).

39. The authors thank the nursing staff of the Tropical Metabolism Research Unit for their meticulous care of these infants, to Jennifer Alexander for technical assistance, to Evadne Forrest for typing the manuscript, and to Ailsa Clarke for preparing the figures. The authors are grateful to the Wellcome Trust for supporting Teresa Cocks and the Helen Hay Whitney Foundation for providing Douglas Kerr with a fellowship. Hazel Robinson gratefully acknowledges the constructive criticism and advice provided by John Waterlow and Michael Golden.

40. The present address of Dr. Douglas Kerr is: Department of Pediatrics, University Hospital of Cleveland, Cleveland, $\mathrm{OH} 44106$.

41. Received for publication April 5, 1978

42. Accepted for publication February 1, 1979 